\title{
Effect of Hydroalcoholic Extract of Oliveria Decumbens Vent on Diarrhea and Symptoms of Morphine Withdrawal Syndrome in Mice
}

Hamideh Shafizadeh Gerdkohi ${ }^{1}$, Vahid Ramezani ${ }^{2}$, Elham Eslahi ${ }^{3}$, Azadeh Emami ${ }^{4}$ Ali mohammad Ranjbar ${ }^{5}$, Fatemeh Tavakoli

1. PharmD, Department of Toxicology and Pharmacology, Faculty of Pharmacy and Pharmaceutical Sciences Research Center, Shahid Sadoughi University of Medical Sciences, Yazd, Iran. ORCID ID: 0000-0002-6844-6389

2. Associate Professor, Department of Pharmaceutics, Faculty of Pharmacy, Shahid Sadoughi University of Medical Sciences, Yazd, Iran. ORCID ID: 0000-0003-4791-6182

3. PhD Student of Microbiology, Department of Microbiology, Shahre Qods Branch, Islamic Azad University, Tehran، Iran. ORCID ID: 0000-0003-4192-2418

4. MSc of Toxicology, Department of Pharmaceutics, Faculty of Pharmacy and Pharmaceutical Sciences Research Center, Shahid Sadoughi University of Medical Sciences, Yazd, Iran. ORCID ID: 0000-0002-0661-9002

5. Assistant Professor, Department of Pharmacogenosy, Faculty of Pharmacy and Pharmaceutical Sciences Research Center , Herbal Medicine Research Centre ,Shahid Sadoughi University of Medical Sciences ,Yazd, Iran .ORCID ID:0000-00022679-7041

6. Assistant Professor, Department of Toxicology and Pharmacology, Faculty of Pharmacy and Pharmaceutical Sciences Research Center, Shahid Sadoughi University of Medical Sciences, Yazd, Iran., (Corresponding Author), Tel: 03538203412, Email: f.tavakoli@ssu.ac.ir, ORCID ID: 0000-0002-5232-7289

\begin{abstract}
Background and Aim: Oliveria decumbens Vent is a medicinal plant used in Iranian traditional medicine for gastrointestinal disorders such as abdominal pain, indigestion and diarrhea. The aim of this study was to evaluate the effect of Oliveria decumbens Vent hydroalcoholic extract on morphine withdrawal symptoms and diarrhea in mice.

Materials and Methods: 40 Mice weighing 20-30g were divided into 5 groups of eight. Negative control and positive control groups received normal saline and loperamide respectively. Treatment groups received 5, 50 and $500 \mathrm{mg} / \mathrm{kg}$ of O.decumbens extract. Morphine dependency was induced by intraperitoneal injection of morphine for seven consecutive days. On the eighth day, one hour after the last dose of morphine, different doses of the extract; normal saline and loperamide were administered intraperitoneally and 30 minutes later naloxone was injected in to all groups to accelerate the onset of withdrawal symptoms. After 10 minutes withdrawal symptoms including jumps, standing and wet dog shakes started. Frequency and water content of stools and quality of stools (normal, loose, watery) were recorded for 60 minutes.
\end{abstract}

Results: The result of this study showed that the extract of $O$. decumbens significantly and dose-dependently decreased the frequency of excretion, jumping, standing on feet, wet dog shakes and the amount of fecal water in the treatment groups compared to those in the control group. $(\mathrm{P}<0.05)$

Conclusion: $O$. decumbens extracts made a significant improvement in morphine withdrawal symptoms and diarrhea.

Keywords: Oliveria decumbens, Diarrhea, Morphine withdrawal syndrome, Medicinal plant Received: Aug 3, 2021 Accepted: Dec 1, 2021

How to cite the article: Hamideh Shafizadeh Gerdkohi, Vahid Ramezani, Elham Eslahi, Azadeh Emami, Ali mohammad Ranjbar, Fatemeh Tavakoli. Effect of hydroalcoholic extract of Oliveria decumbens Vent on diarrhea and symptoms of morphine withdrawal syndrome in mice. SJKU. 2021;26(3):1-12.

Copyright ( $\odot 2018$ the Author (s). Published by Kurdistan University of Medical Sciences. This is an open access article distributed under the terms of the Creative Commons Attribution-Non-Commercial License 4.0 (CCBYNC), where it is permissible to download, share, remix, transform, and buildup the work provided it is properly cited. The work cannot be used commercially without permission from the journal 


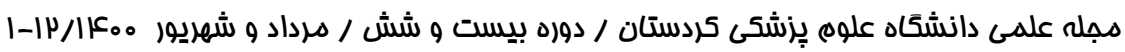

\section{اثر عصاره هيدروالكلى تياه لعل كوهستان (Oliveria Decumbens Ven) بر اسهال و

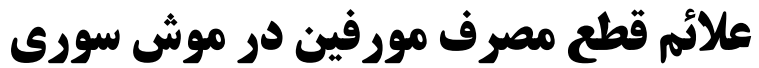

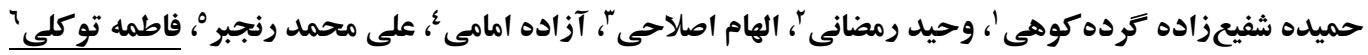

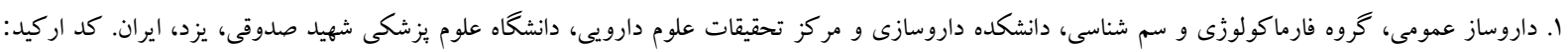

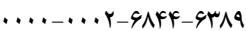
r. دانشيار، گروه فارماسيو تيكس، دانشكده داروسازى ، دانشكاه علوم يزشكى شهيد صدوقى يزد، ايران. كد اركيد:

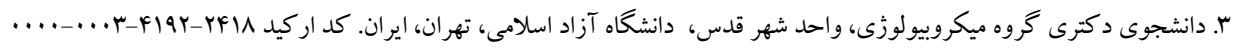

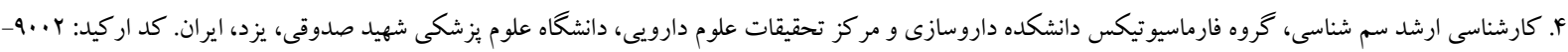
$.991-\cdots .+. \cdots$. ه. استاديار گروه فارماكو گنوزى، دانشكده داروسازى و مركز تحقيقات علوم دارويى، مركز تحقيقات گياهان دارويى ، دانشكاه علوم يز شكى شهيد صدوقى يزد، ايران.

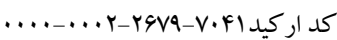

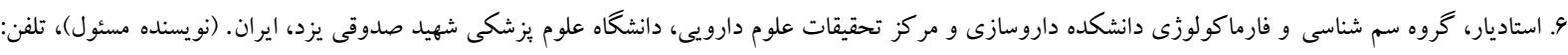

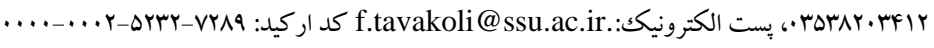

جكيuه زمينه و هدف: لعل كوهستان با نام علمى Oliveria decumbens vent ازگياهان دارويى ايران است كه در طب سنتى براى درمان مشكلات گوارشى مانند دردهاى شكمى، سوءهاضمه و اسهال استفاده مى شده است. هدف از مطالعه حاضر بررسى اثر عصاره هيدروالكلى گياه لعل كوهستان در درمان اختلالات گوارشى بهويزه اسهال و كاهش علائم سندرم ترك ناشى از مورفين در مارد موش سورى است.

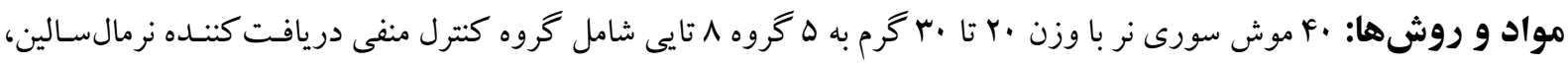

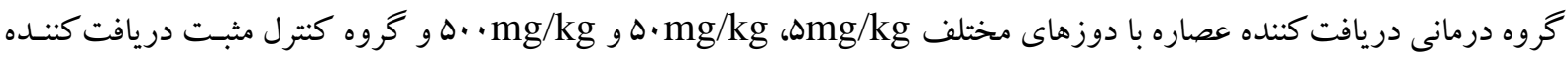
لوير اميد تقسيم شدند. وابستكى به مورفين با تزريق داخل صفاقى مورفين بـه مـدت V روز متـوالى ايجـاد شـد. در روز هشـتم، يـك ساعت بس از آخرين دوز مورفين، دوزهاى مختلف عصاره، نرمالسالين و لوير اميد به صورت داخل صفاقى بـه گروههـاى مربوطـه تجويز شد و ·r دقيقه بعد نالو كسان به همه گروهها تزريق شد تا شروع علائم تركك را تسريع كند و يس از · •ادقيقه علائم سـندرم تركى شامل يرش، ايستادن روى ياها، حر كات شبيه سگك خيس و اسهال كه شامل كيفيـت مـدفوع (معمـولى، نـرم، آبكى)، تعـداد دفعات دفع و محتوى آب مدفوع است، به مدت .9 دقيقه با مشاهده مستقيم يادداشت و ثبت شد. يافته ها: نتايج اين مطالعه نشان داد كه عصاره گياه لعل كوهستان به صورت وابسته به دوز و معنىدارى سبب كاهش تعداد دفعات

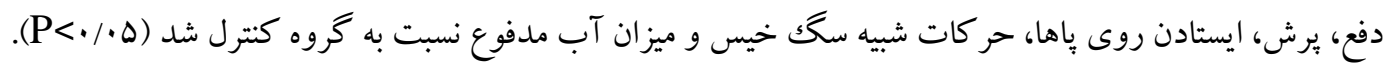
نتيجه تيرى: بر هايه نتايج اين مطالعه عصاره لعل كوهستان اثر قابلملاحظهاى در درمان اسهال و كاهش علائم سندرم ترك ناشى از مورفين دارد وازههاى كليدى: لعل كوهستان، اسهال، سندرم ترك مورفين، داروهاى گياهى

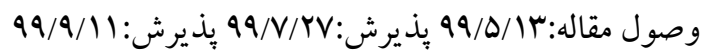


يديدار مى شود علائم اصلى اين سندرم شامل علائم جسمى

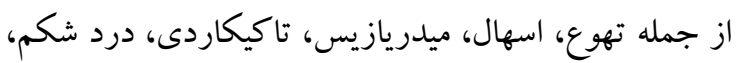
درد مفصل و درد عضلانى، كاهش اشتها و علائم روحى از

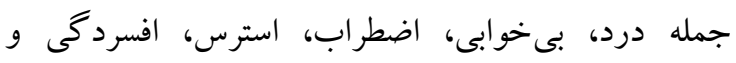

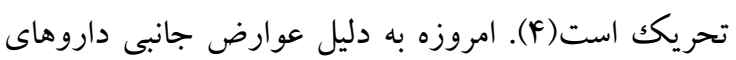

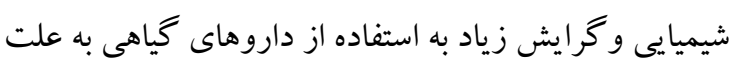

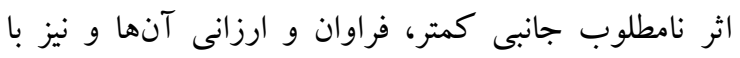
توجه به استفاده از گياه لعل كوهستان در درمان مشكلات كوارشى نظير اسهال، مطالعه حاضر براى اولين بار به منظور بررسى اثر عصاره هيدروالكلى اين خياه در درمان اختلالات

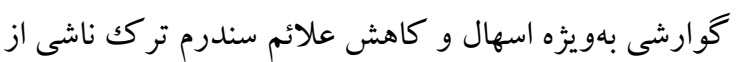
مورفين در موش سورى انجام شده است.

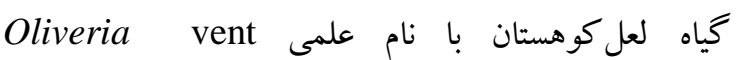
decumbens از خانواده Apiaceae است كه يك گياه اندميك فلور ايران است و در مناطق گرمسيرى جنوب و و جنوب غرب ايران رشد مى كند. اين كياه كه با نامهاى محلى "denak"، و "denakhkorak" شناخته شدهو در طب سنتى براى دلييجه، اسهال، دردهاى شكمى و تب

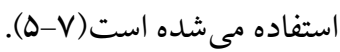
مطالعات ارزشمندى در مورد اثر درمانى گياه لعل كوهستان و شناسايى تركيبات آن انجام شده است، از جمله در سال

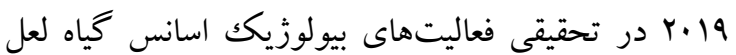
كوهستان مورد بررسى قرار گرفته و اثر آنتى باكتريال قوى

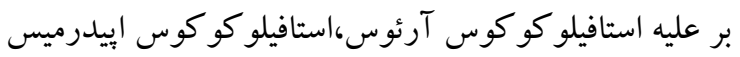
و اشرشياكولاى مشاهده شد و نيز اثر آنتى هليكوباكتر يبلورى آن و تيمول (به عنوان تركيب اصلى اسانس) مورد

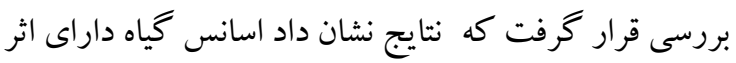

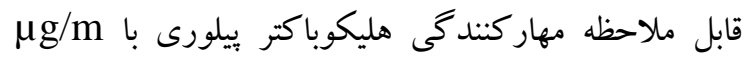
MIC=r./4

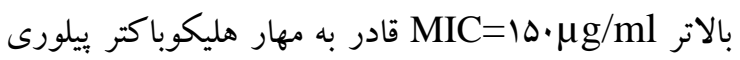

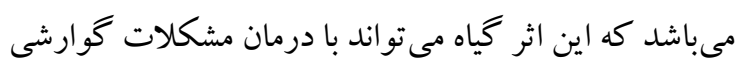

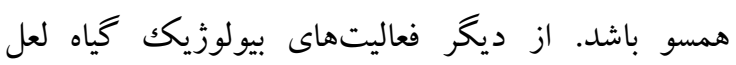

مقدمه

اختلالات دستخاه گوارش يكى از اختلالات با شيوع بالا در جوامع انسانى است(1). دستخاه گُوارش يكى از مهم ترين

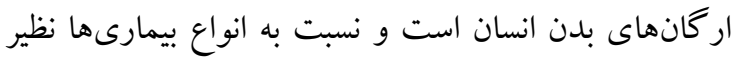

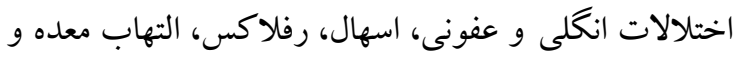
روده، يبوست و نفخ آسيبذيذير هست. امروزه اسهال يكك ونك مشكل بهداشتى در جهان به ويزه در كودكان است(1).

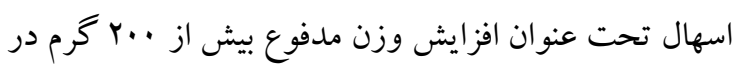

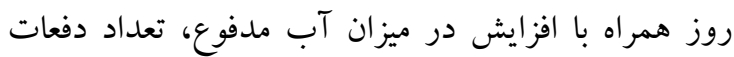

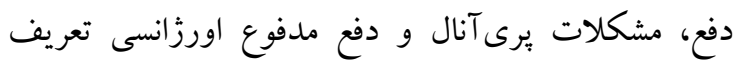

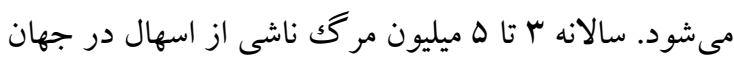

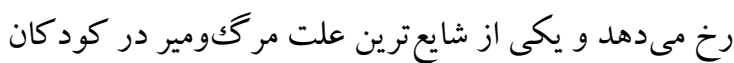

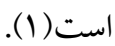

به علت عوارض جانبى غيرقابل اجتناب داروهاى سنتيكك، شناسايى داروهاى جديد با حداقل عوارض جانبى بسيار مورد توجه قرار گرفته شده است( (1). ازجمله اين داروها،

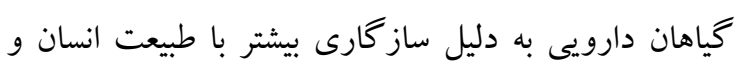
عوارض جانبى كمترى كه دارند مىباشند(r, r,

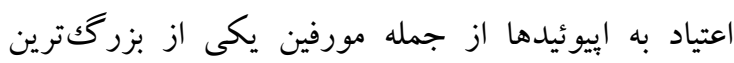
مشكلات سيستم سلامت است. درمان اعتياد يك اقدام برنامهريزى شده است كه هدف آن كاهش مصرف مواد و يا متوقف كردن آن و همجنين جلو گيرى از عود مجدد آن است(F). إيوئيدها بر گيرندهاى اختصاصى (مو، دلتا، كايا و...) اثر دارند. مواد مخدر با فعال نمودن طولانىمدت فيرتئ كيرندهاى إيوئيد، از إيوئيدهاى درونزا تقليد مى كنند كه

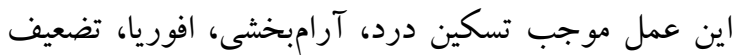
تنفسى، يبوست، تهوع و ميوزيس مى كردد. اثرات طولانىمدت ناشى از مصرف مو اد إيوئيدى، تحمل و

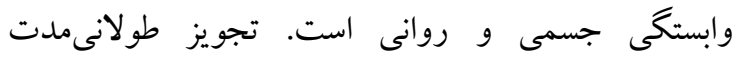

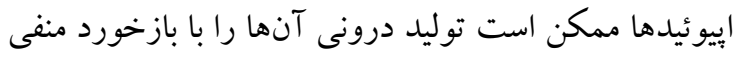
متوقف نمايد به طورى كه اخر دارو قطع شود يكك كمبود

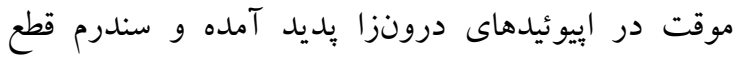


دريافت كرده بودند، ميزان آنزيمهاى ALT، AST و ALP كاهش معنى دارى را نشان دادند. بر گشت آنزيمهاى فوق به حالت طبيعى توسط عصاره هيدرو الكى لعل كوهستان دليل واضحى بر اثرات حفاظتى اين گياه است كه احتمال دارد علت آن خاصيت آنتىاكسيدانى تركيبات مؤثر لعل كوهستان باشد كه با ايجاد ثبات غشايى در سلولها موجب حفاظت از سلولهاى كبدى در مقابل استرس اكسيداتيو شده و مانع از آزاد شدن آنزيمهاى كبدى به سرم شده

است(1).

\section{مواد و روشها}

در اين مطالعه تجربى جهت ارزيابى درونتن اثر ضد اسهال كياه لعل كوهستان، با استفاده از تجويز داخل صفاقى مورفين به مدت ^ روز موش ها معتاد شدند. سيس به دنبال قطع مورفين و تجويز نالو كسان، مدل حيو انى اسهال ناشى از سندرم تركك مورفين ايجاد شد. روش تجزيه و تحليل آمارى: براى يافتن اختلاف معنىدار بر ميزان بروز سندرم ترك مورفين در گروههاى مختلف مورد بررسى از آناليز واريانس استفاده شد. نتايج كاهش در سندرم ترك مورفين بهوسيله آزمون آناليز واريانس يككطرفه (ANOVA) مقايسه شد. سֶّ آزمون dunnett براى مقايسه گرووهها با گروه كنترل به كار گرفته شد. ارائه نتايج بر اساس mean I SEM بوده

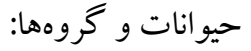

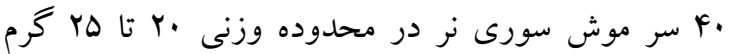
انتخاب شدند. حيوانات به طور تصادفى به ه گروه مساوى شامل: گروه كنترل منفى نرمالسالين، گروههاى درمانى

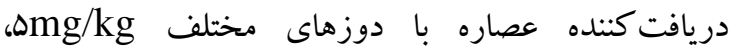

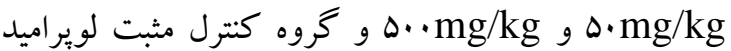
تقسيم شدند. حيوانها در دماى هY-r.r درجه سانتى گراد و شرايط نورى Yl ساعت روشنايى و Ir ساعت تاريكى
كوهستان كه در اينمطالعه بررسى شد فعاليت سيتو تو كسيك اسانس بوده است كه نتايج بيانگر اين مطلب است كه اسانس گياه داراى اثر مهاركنندگى قوى عليه همه ردههاى سلولى سرطانى به كار برده شده در اين تحقيق مىباشد. به طور كلى بر طبق اين مطالعه، مشخص شده كه اسانس كياه لعل كوهستان كه حاوى مقدار بالايى از تيمول و كارواكرول است كه مىتواند منبع مؤثرى به عنوان آنتى باكتريال، آنتى هليكو باكتر ييلورى و سيتوتو كسيك باشد(ץ). در بثزوهشى

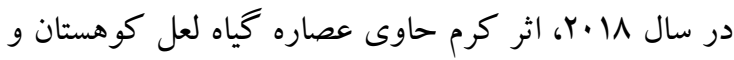
شمعدانى بر روى مدل زخم ياى ديابتى در رت صورت كرفت و مشخص شد كه كرم حاوى هر دو گياه داراى اثر بهبودى زخم و بازسازى بافت است در اين مطالعه براى اولين بار اثر بهبود زخم و ضد التهاب كياه لعل كوهستان

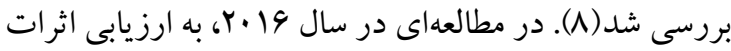
فرمولاسيون گياهى حاوى اسانس گياه لعل كوهستان و شمعدانى معطر در برابر عفونت بوستى ايجاد شده توسط استافيلو كوك آرئوس مقاوم به متىسيلين (MRSA) در موش سورى يرداخته شده و اثرات قابل توجه در بهبود وترميم زخم يوستى مشاهده شد. با توجه به نتايج اين مطالعه مىتوان كياهان دارويى لعل كوهستان و شمعدانى معطر را در درمان زخمهاى بوستى آلوده توصيه كرد(9). در تحقيق ديخرى كه در سال 19 ب انجام شد خاصيت ضد ويروسى عصاره گياه لعل كوهستان در كنترل ويروس هريس سيميلكس نوع يكك به روش MTT assay ارزيابى شد. نتايج اين بزوهش نشان داد كه مؤثرترين زمان اثر عصاره هنگامى است كه ويروس با غلظتهاى مختلف عصاره به مدت r ساعت قبل از آلوده نمودن سلولها، كرم خانه گذارى گردد (1)

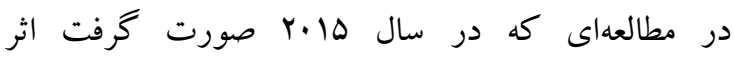
هياتويروتكتيو عصاره هيدروالكلى لعل كوهستان در برابر مسموميت كبدى القاشده با كلريد كادميوم در موش صحرايى مورد بررسى قرار گرفت. در موش هايى كه علاوه بر كلريد كادميوم عصاره هيدروالكلى لعل كوهستان را 


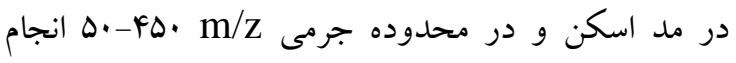

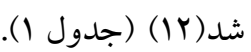
روش ايجاد سندرم تركك مورفين در موش سورى:

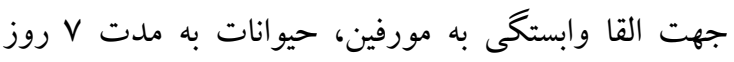
دوزهاى مختلف مورفين را به روش داخل صفاقى در ساعت هاى ^صبح و ^ شب دريافت كردند. غلظت مورفين با الكوى زير افزايش يافت: روز اول ور و دوم

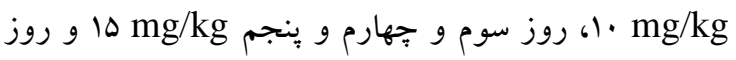

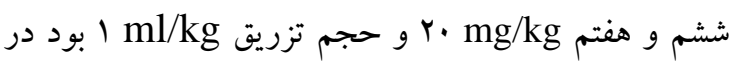
روز هشتم در ساعت ^ صبح آخرين دوز مورفين با غلظت ونت تجويز شد و يكك ساعت پِ r.mg/kg

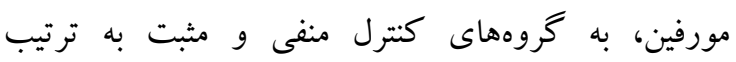

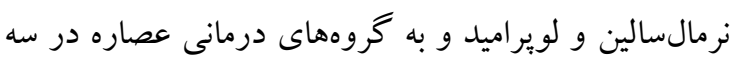
دوز تجويز شد. نيم ساعت بعد نالوكسان با غلظت

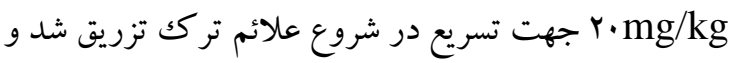
بس از •ا دقيقه علائم سندرم محروميت شامل برش،

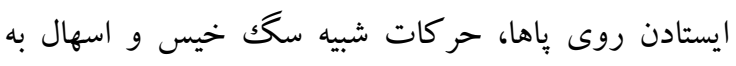
مدت .9 دقيقه با مشاهده مستقيم يادداشت و ثبت شد(با). كيفيت مدفوع (شامل معمولى، نرم، آبكى)، تعداد دفعات

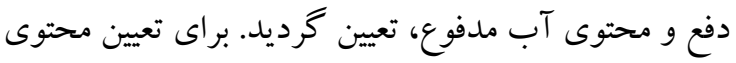

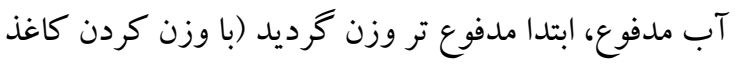
صافى) و سبس كاغذهاى صافى به مدت FF ساعت در آون در دماى •هه درجه سانتى گراد قرار داده شد تا مدفوع خشك شود. با تعيين اختلاف وزن مدفوع تر و خشكك،

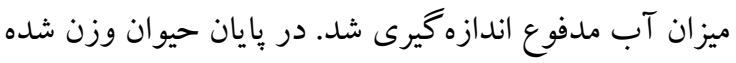

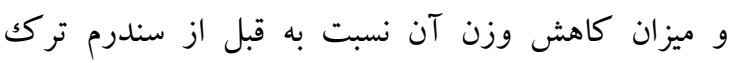
مورفين محاسبه كرديد.
نخهدارى شدند و آب و غذا آزادانه در اختيار آنها قرار كرفت. اصول اخلاقى كار با حيوانات آزمايشگاهى مطابق با جكك ليست ابلاغى وزارت بهداشت، رعايت گرديد. تهيه عصاره لعل كوهستان: قسمتهاى هوايى گياه لعل كوهستان از منطقه گخجساران

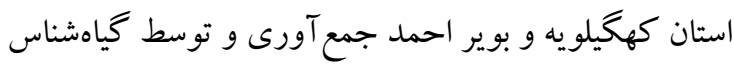

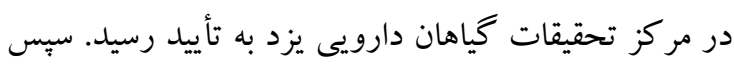

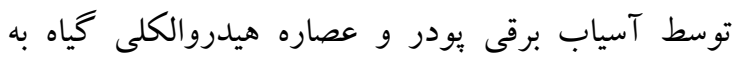

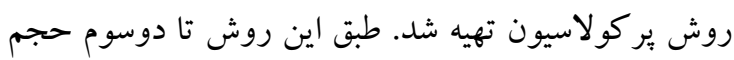

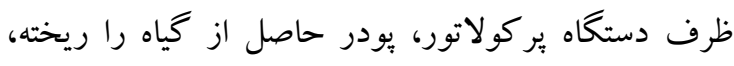

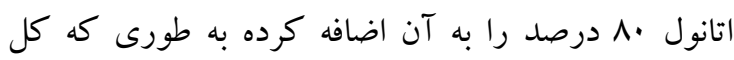

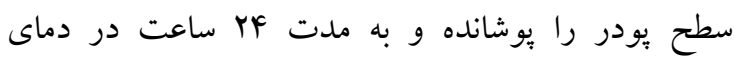

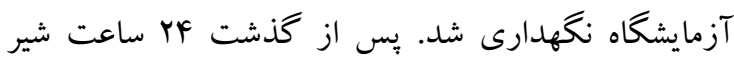

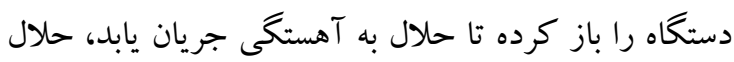
مواد مؤثره را در خود حل نموده و خارج مى شود. جندين بار اين عمل راطى يكك هفته تكرار مى كنيم تا عصاره غليظ

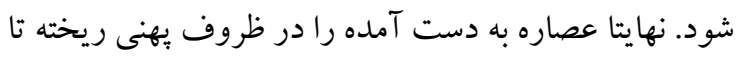

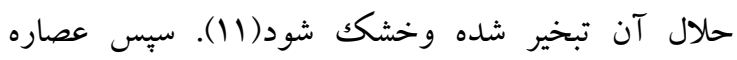

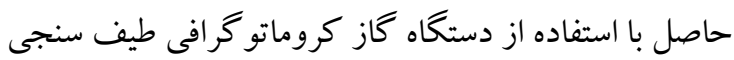
جرمى (GC/MS) آناليز و تركيبات موجود در آن شناسايى

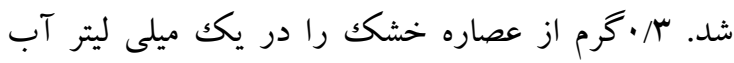
مقطر حل كرده وبعد از حل شدن و سانتريفيوز كردن عصاره ץميكروليتر از آن را به دستخاه گاز كروماتو كرافى

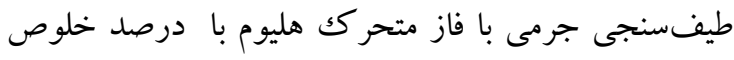

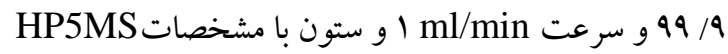
(30 $\mathrm{m} \times 0.25 \mathrm{~mm}$ I.D. , $0.25 \mu \mathrm{m}$ film thickness ) در دماى • بَ به صورت splitless تزريق و شناسايى ابتدا 
4

جدول ا. تركيبات موجود در عصاره كياه لعل كوهستان

\begin{tabular}{|c|c|c|c|c|c|}
\hline شماره & زمان & $\begin{array}{r}\text { مساحت زير } \\
\end{array}$ & منحنى ارتفاع & تر ترصد & نام تر كيبات \\
\hline 1 & $9 / \cdot M F$ & $90111 \mathrm{~V}$ & IrYAQT & $\% 1 /$ ro & او זو سوع تتر امتيل بنزن \\
\hline r & IT/YGA & $19 \ldots 9 v r$ & $r .190 \mathrm{~V}$ & $\% r / .+q$ & r ايزويروييل فنل \\
\hline r & IF/FFG & IMAVmIV & r. QrVGA & $\%, r \cdot / r F F$ & كارواكرول \\
\hline r & $\mid F / \Delta V F$ & rardID.r & rMaYIVI & $\%$ rq/ı^r & تيمول \\
\hline$\Delta$ & $|N / Y| \Lambda$ & $r \cdot A Y I D F q$ & IDVFFYF & \% rY/FFF & ميريستيسين \\
\hline 9 & MN/VYr & $9949 \cdot 19$ & $9 \cdot 1994$ & $\%$ V/lar & انسيكلوهكَيل آنيلين \\
\hline$\checkmark$ & $r F / M I D$ & rar. rgF & l19OANT & $\% / / F A$ & اتيل پِالميتات \\
\hline$\wedge$ & YG/YGD & IrraqGF & $\Delta F I . F$. & $\% 1 / r T V$ & اتيل لينوئيت \\
\hline 9 & re/rIV & ro. 19Vr & WairV & $\% / 9 / 99 V$ & اتيل اولئيت \\
\hline 1. & $r 9 / 911$ & ovallr & 191.94 & $\% \cdot / 9 Y 1$ & اتيل استئارات \\
\hline
\end{tabular}

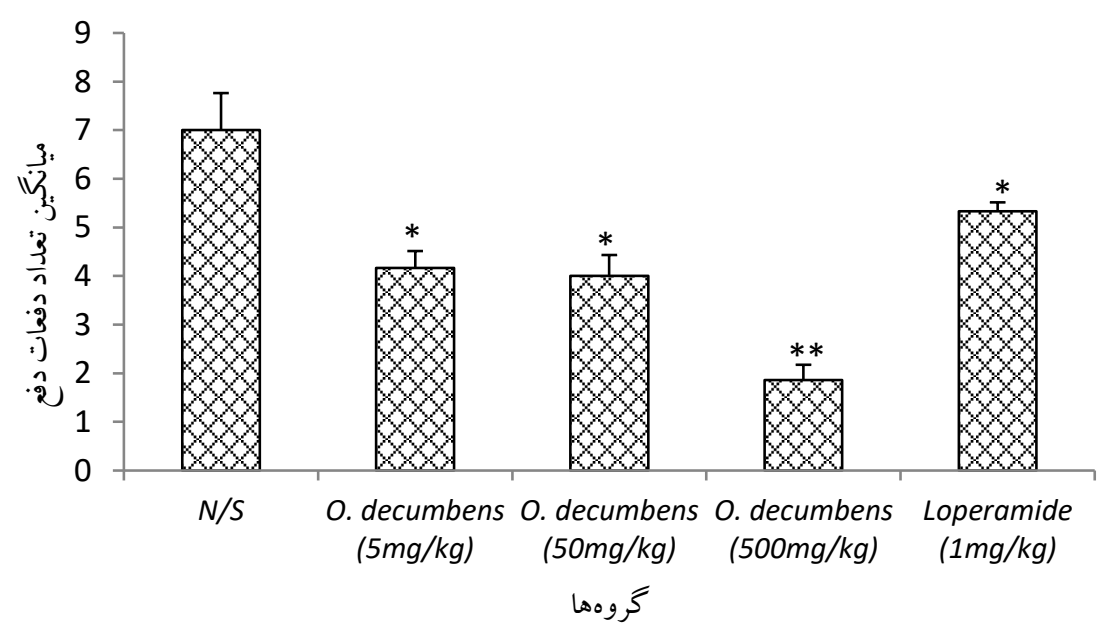

نمودار ا. مقايسه تعداد دفعات دفع در گروههاى مختلف موشهاى وابسته به مورفين.

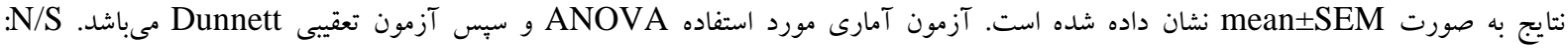

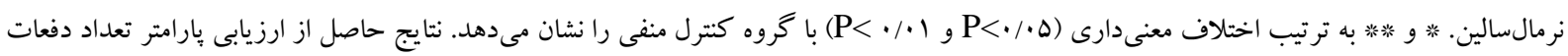

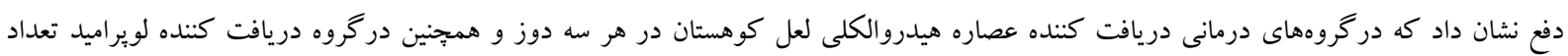

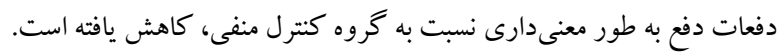

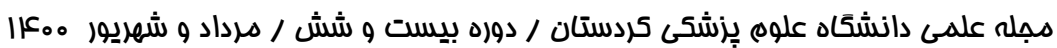




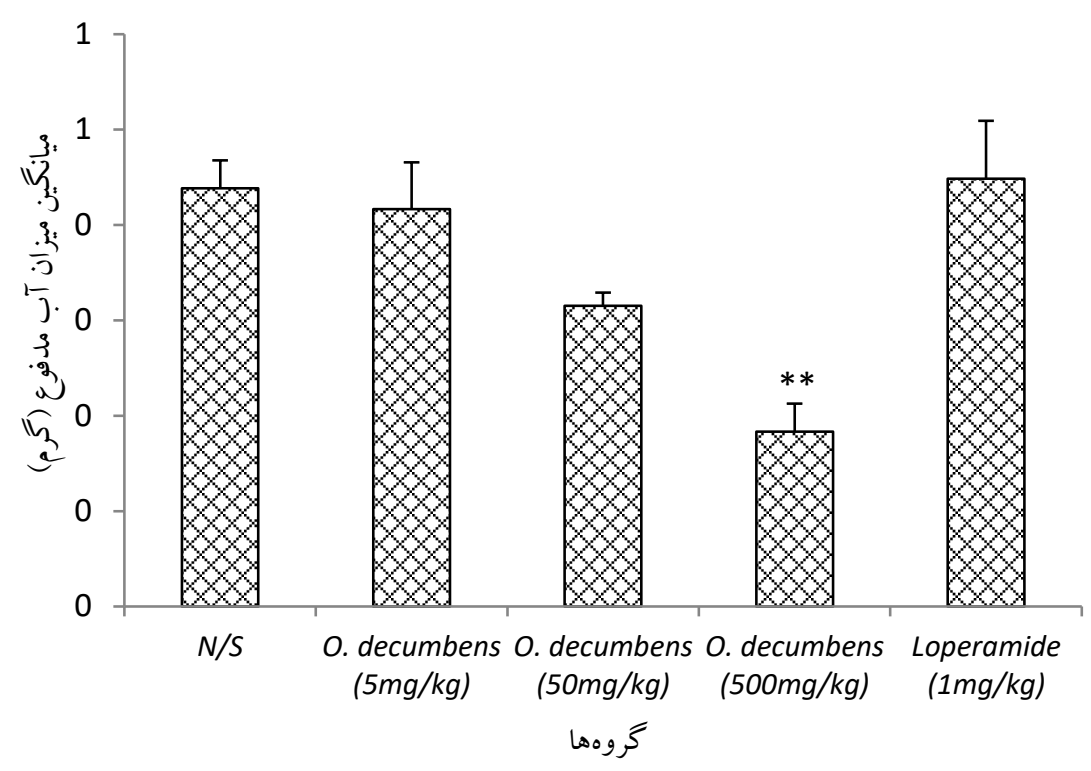

نمودار ז. مقايسه ميزان آب مدفوع در كروههاى مختلف موشهاى وابسته به مورفين.

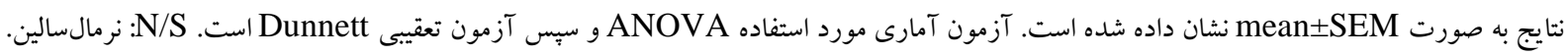

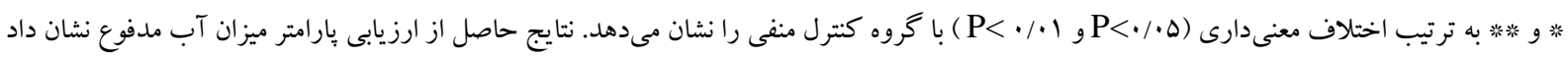

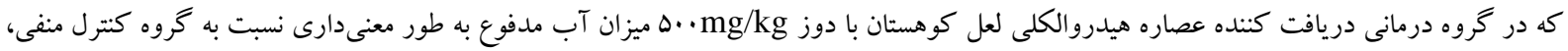
كاهش يافته است.

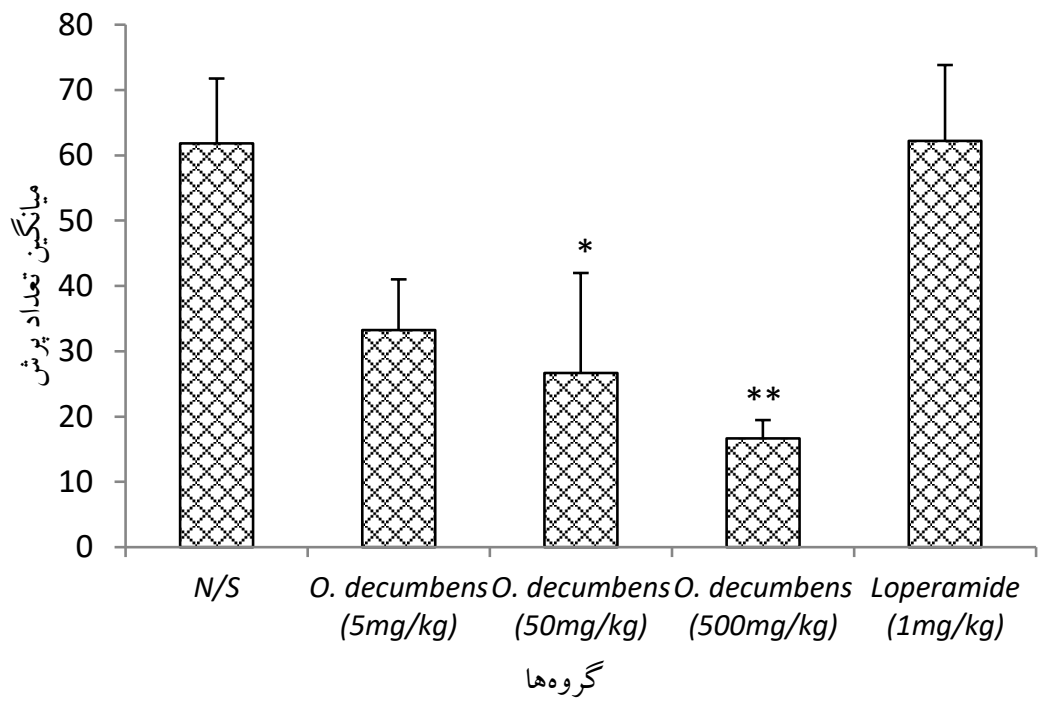

نمودار r. مقايسه تعداد يرش در زروههاى مختلف موشهاى وابسته به مورفين است.

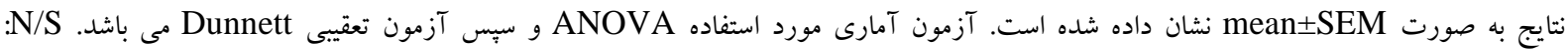
نرمالسالين.

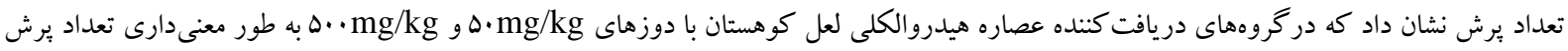
نسبت به گروه كنترل منفى كاهش يافته است. 


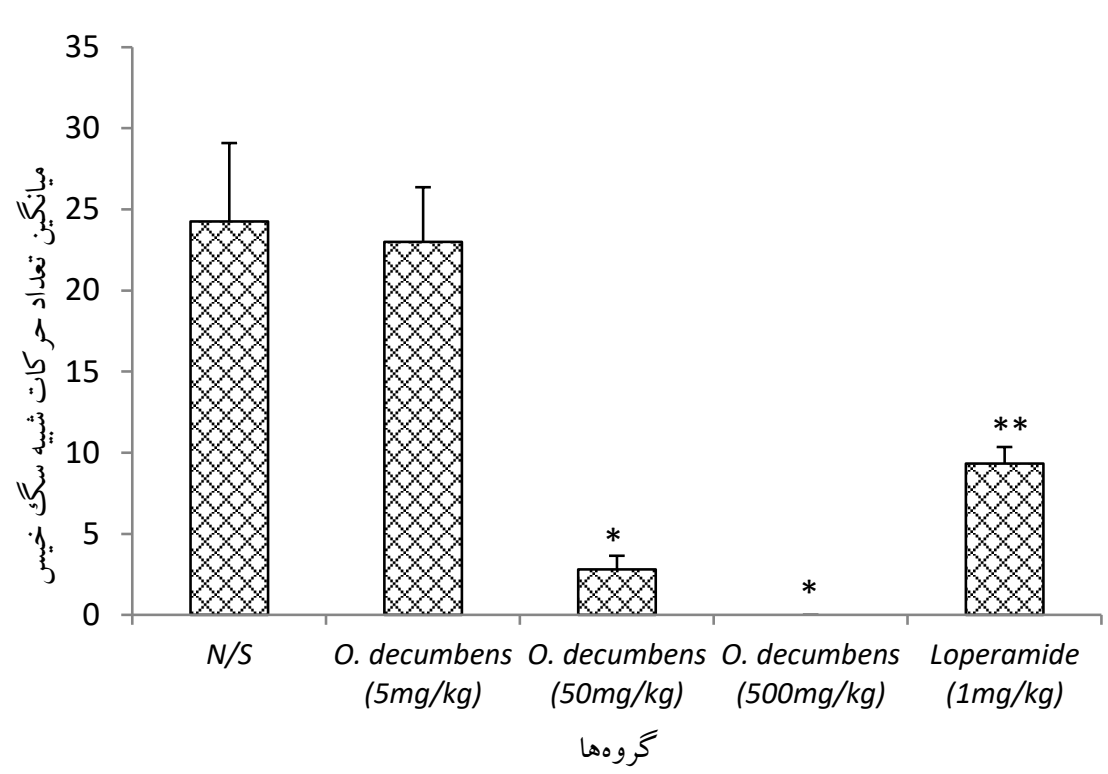

نمودار ع. مقايسه تعداد حر كات شبيه سك خيس در كروههاى مختلف موشهاى وابسته به مورفين.

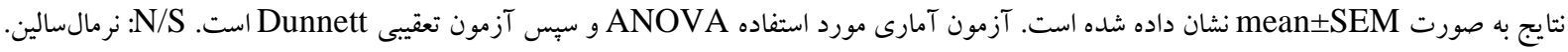

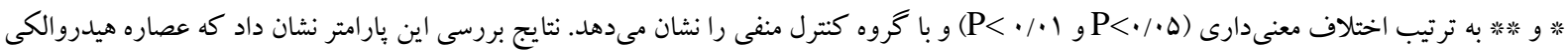

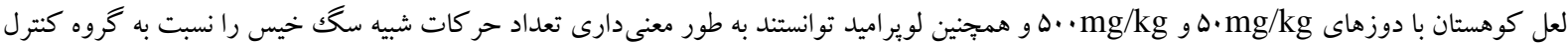
منفى، كاهش دهند.

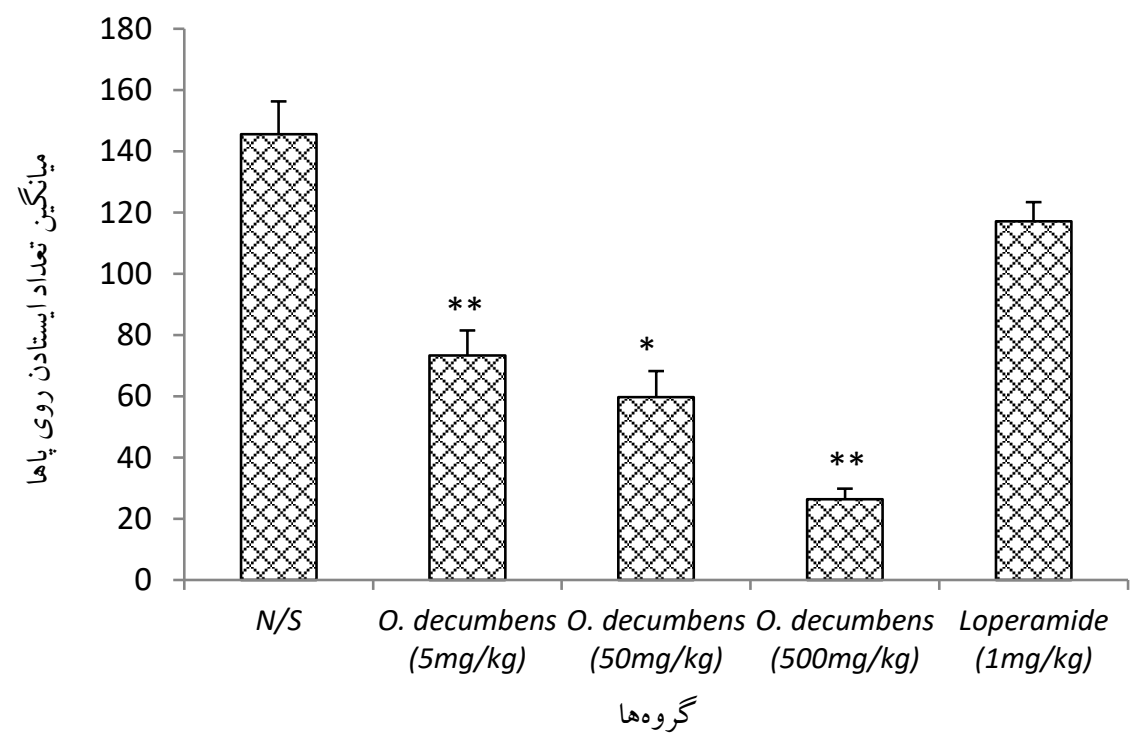

نموداره. مقايسه تعداد ايستادن روى ياها در گروههاى مختلف موشهاى وابسته به مورفين.

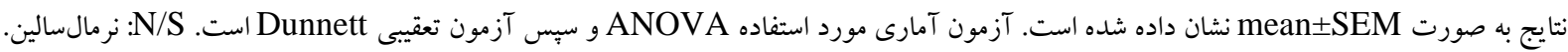

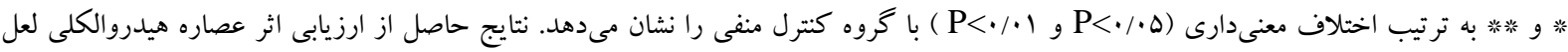

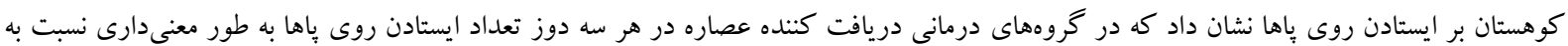
كروه كنترل منفى، كمتر بود.

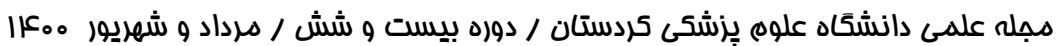


كروه دريافت كننده لوبراميد ميزان آب مدفوع را كاهش به طور خلاصه نتايج حاصل از ارزيابى بارامتر ميزان آب مدفوع نشان داد كه در گروه درمانى دريافت كننده عصاره با دوز موله/lkg ميزان آب مدفوع به طور معنىدارى

$$
\text { نسبت به گروه كنترل منفى كاهش داده است. }
$$

نتايج حاصل از بررسى بارامتر كيفيت مدفوع نشان داد كه حيوانات كروه كنترل منفى غالباً كيفيت مدفوعشان نرم است در حالى كه بقيه گروههاى تحت درمان با عصاره و گروه

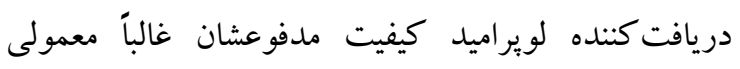

اثر عصاره كياه لعل كوهستان در تعداد برش ناشى از سندرم ترك مورفين در موش سورى:

نتايج به دست آمده با توجه به نمودارس نشان مىدهد كه مورس

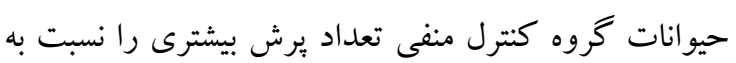
كروههاى ديخر داشتهاند. گروه دريافت كننده عصاره با دوز ه mg/kg تعداد برش را كاهش داده است؛ ولى در مقايسه با گروه كنترل اين كاهش معنىدار نبوده است. گرووهاى

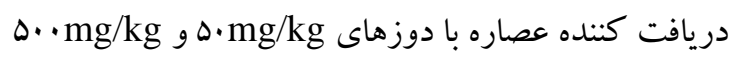

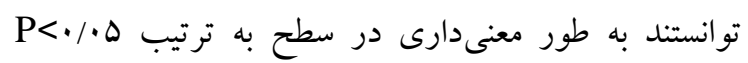
و P> P Pر كاهش تعداد يرش در موش سورى مؤثر باشند. لوبراميد تعداد يرش را در موش كاهش نداده است.

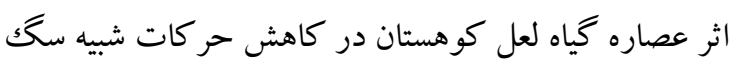
خيس ناشى از سندرم تركك مورفين در موش سورى نتايج به دست آمده با توجه به نمودار F نشان مىدهد كه حيوانات كروه كنترل منفى تعداد حر كات شبيه سگك خيس بيشترى را نسبت به گروههاى ديگر داشتهاند. گروه دريافت كننده عصاره با دوز mg/kg ه در كاهش حركات شبيه سگ خيس مؤثر نبوده است. گروههاى دريافت كننده عصاره با

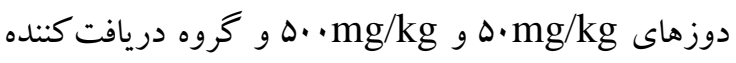
لويراميد در مقايسه با گروه كنترل به طور معنىدارى در نتايج حاصل از آناليز عصاره گياه لعل كوهستان در جدول شماره ا نشان داده شده است. بر طبق اين جدول در مطالعه

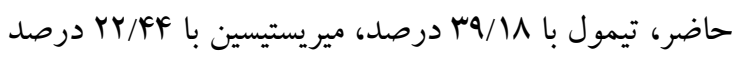

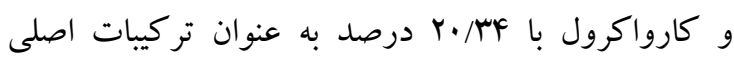
عصاره گياه لعل كوهستان شناسايى شدند. اثر عصاره لعل كوهستان بر اسهال: در ارزيابى اثر عصاره لعل كوهستان بر اسهال ب بِارامتر

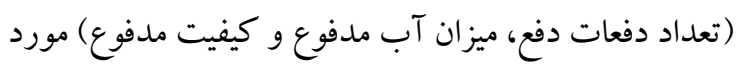
بر برسى قرار گفت.

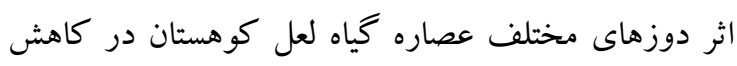

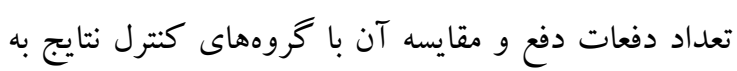

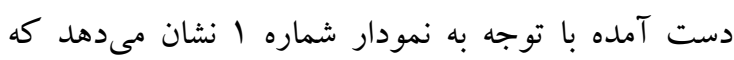
حيوانات گروه كنترل منفى كه دريافت كننده نرمالسالين

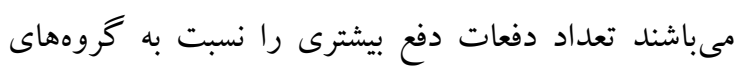

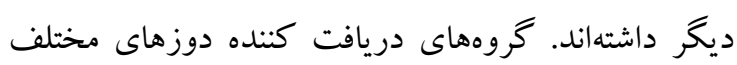

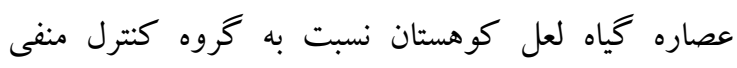

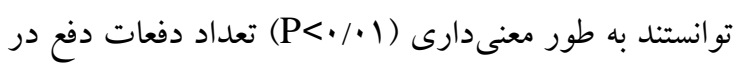
موش را كاهش دهند. گروه دريافت كننده لويراميد هم به

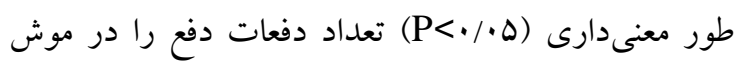

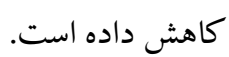
اثر دوزهاى مختلف عصاره گياه لعل كوهستان در كاهش داده الت

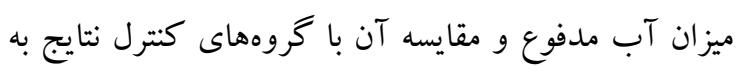

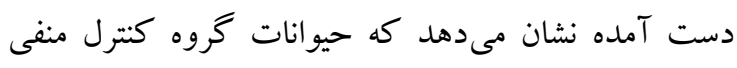
ميزان آب مدفوع بيشترى را نسبت به گروههاى ديخر داشته اند. گروههاى دريافت كننده عصاره گياه با دوزهاى

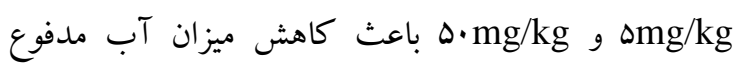

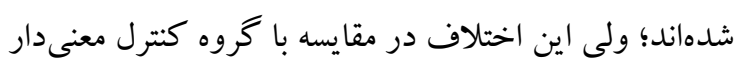

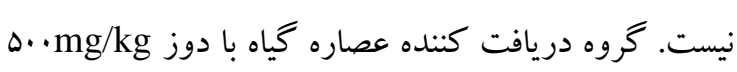

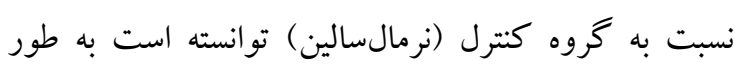

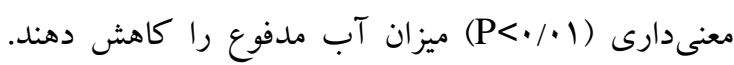


1 ا اثر عماره هيدروالكلى...

دوز كروه كنترل داشت؛ اما گروههاى دريافت كننده عصاره كياه در دو دوز ه.mg/kg و ه دريافت كننده لويراميد نسبت به گروه كنترل اختلاف معنىدارى نداشتند. بارامتر آخر مورد بررسى در اسهال كيفيت مدفوع بود كه در كروه كنترل منفى اغلب نرم و در كروههاى دريافت كننده عصاره به صورت معمولى مشاهده شد. همانطور كه از نتايج مشاهده مى گردد، عصاره گياهى لعل كوهستان به صورت معنىدارى سبب كاهش بار امترهاى مورد بررسى اسهال در اين بزوهش شد و اين امر به صورت علمى تأييد كننده مطالبى است كه در طب سنتى در مورد استفاده از اين كياه در اختلالات گوارشى از جمله اسهال بيان شده است. در بررسى تأثير عصاره گياه لعل كوهستان بر ديخر علائم سندرم ترك مورفين، نتايج نشان دادند كه اين عصاره مى تواند به صورت وابسته به دوز باعث كاهش اين

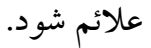

تاكنون مطالعات ارزشمندى در مورد اثر درمانى انواع كياهان دارويى بر اسهال و كاهش علائم سندرم ترك ناشى از مورفين در ايران انجام شده است(IV-IF). از جمله در مطالعهاى در سال 19 ب اثر عصاره هيدروالكلى شيرين بيان بر اسهال تجربى القا شده با روغن كرجّك در موش سورى بررسى شد و نتايج اين تحقيق نشان داد كه اين عصاره به شكل وابسته به دوز باعث مهار ترانزيت نرمال در رودهها مى گردد؛ بنابراين مىتواند در باز جذب بيشتر آب و و الكتروليت نقش داشته و در نتيجه مانع از بروز اسهال در موشها كردد كه يكى از دلايل احتمالى ضد اسهالى عصاره اين كياه مىتواند باشد(1) (1). در تحقيقى در سال 11 ·r تأثير عصاره هيدروالكلى آوندول بر سندرم ترك (Boiss cordifolium Smyrnium) اعتياد در موش سورى در مقايسه با كلونيدين انجام و نتايج حاصل از آن نشان داد كه اين عصاره موجب كاهش علائم سندرم تركك اعتياد در موشهاى وابسته به مورفين شد كه از
سطح 1+1 حر كات شبيه سگك خيس را در موش كاهش داده اند.

اثر عصاره گياه لعل كوهستان در كاهش ايستادن روى باها ناشى از سندرم تركك مورفين در موش سورى: ارزيابى نتايج با توجه به نمودار ه، حاكى از آن است كه حيوانات گروه كنترل منفى تعداد ايستادن روى بِاهاى بيشترى را نسبت به گروههاى ديخر داشتهاند. گرووهاى دريافت كننده عصاره با دوزهاى ه ه ه و و و ه در مقايسه با كروه كنترل توانستند به طور معنىدارى در سطح 1 P>• در كاهش ايستادن روى باها مؤثر باشند. گرووه دريافت كننده لويراميد ايستادن روى باها در موش را كاهش داده؛ ولى در مقايسه با گروه كنترل اين كاهش معنى دار نبوده است.

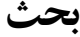

در يثزوهش حاضر اثر عصاره هيدروالكلى گياه لعل كوهستان بر اسهال و علائم ناشى از سندرم تركك مورفين مورد بررسى قرار گرفت و نتايج حاكى از اثربخش بودن اين كياه در كاهش اسهال و علائم ديخر سندرم ترك مورفين مانند يرش، ايستادن روى باها، حر كات شبيه سگك خيس در حيوانات مورد بررسى بود. در بررسى اثر عصاره گياه لعل كوهستان در كاهش اسهال ناشى از سندرم تركك سه يارامتر تعداد دفعات دفع، ميزان آب مدفوع و كيفيت مدفوع مورد بررسى قرار كرفت. ارزيابى يارامتر تعداد دفعات دفع نشان داد كه تجويز عصاره

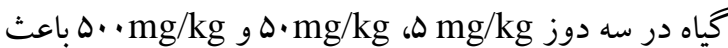

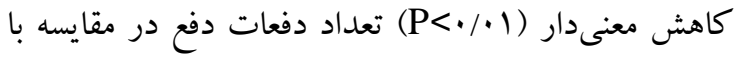
كروه كنترل شد. كروه دريافت كننده لوبراميد هم با كروه كنترل داراى اختلاف معنى دارى (ه•/P>•(P) بود؛ ولى سه گروهدرمانى با عصاره گياه نسبت به گرووه دريافت كننده لويراميد تعداد دفعات دفع را بيشتر كاهش دادند. يارامتر ديخر مورد بررسى در اسهال ميزان آب مدفوع بود كه در گروه عصاره گياه با 


$$
\begin{aligned}
& \text { بهعنوان آنتىاسياسموديك مى تواند يكى از دلايل احتمالى }
\end{aligned}
$$

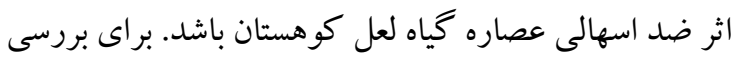

$$
\begin{aligned}
& \text { دقيق مكانسيم كاهش علائم سندرم تركك ناشى از مورفين از } \\
& \text { جمله اسهال نيازمند مطالعات بيشترى است. }
\end{aligned}
$$

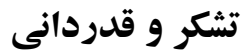

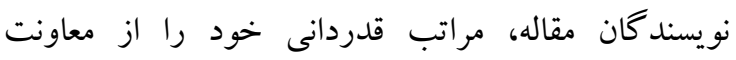

$$
\begin{aligned}
& \text { يثزوهشى و مر كز تحقيقات علوم دارويى دانشكده داروسازى } \\
& \text { علوم يزشكى شهيد صدوقى يزد بهواسطه تأمين هزينه و }
\end{aligned}
$$

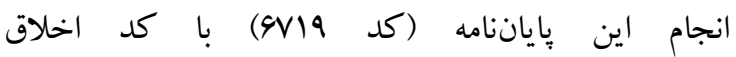

$$
\begin{aligned}
& \text { I ا اعلام IR.SSU.MEDICINE.REC.1397.095 } \\
& \text { مىدارند. اين پاياننامه در سال ^هبا در اين دانشكده } \\
& \text { تصويب و در آزمايشگاه گياهان دارويى و فارماكولوزي لهاني } \\
& \text { انجام شده است لازم به ذكر است كه هيج كدام از } \\
& \text { نويسند كان اين مطالعه، تعارض منافعى براى انتشار اين مقاله }
\end{aligned}
$$

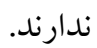$$
\text { دلايل احتمالى اين تعديل، فعال نمودن مسيرهاى إيوئيدى، }
$$

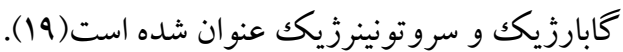$$
\text { با آناليز عصاره گياه لعل كوهستان در اين مطالعه (جدول ())، }
$$

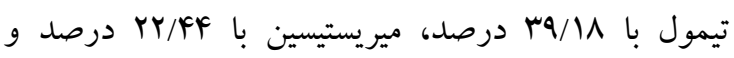

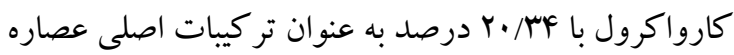

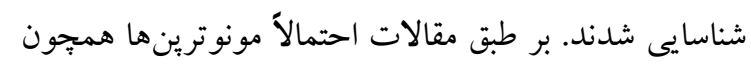

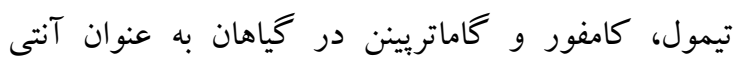

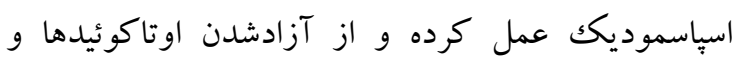

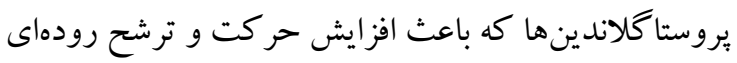

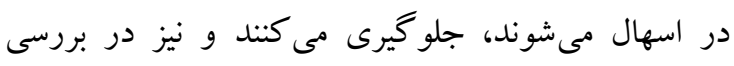$$
\text { مقالات مذكور حضور تركيباتى مانند تيمول، فلاونوئيد و }
$$$$
\text { مشتقات ترينوئيدى يكى ازدلايل احتمالى كاهش على علائم }
$$$$
\text { سندرم تر كك اعتياد با مورفين شناخته شده است. }
$$

1. Bahmani M, Zargaran A, Rafieian-Kopaei M. Identification of medicinal plants of Urmia for treatment of gastrointestinal disorders. Rev Bras Farmacogn. 2014;24(4):468-80.

2. Karami A, Khoshbakht T, Esmaeili H, Maggi F. Essential Oil Chemical Variability inOliveria decumbens(Apiaceae) from DifferentRegions of Iran and Its Relationship with Environmental Factors. Plants. 2020;9(6):1-13.

3.Eftekhari M, Ardekani Sham MR, Amin M, Attar F, Akbarzadeh T, Safavi M, et al. Oliveria decumbens, a bioactive essential oil: Chemical composition and biological activities. IJPR. 2019;18(1):412-21.

4. Ebrahimie M, Bahmani M, Shirzad H, Rafieian-Kopaei M, Saki K. A review study on the effect of Iranian herbal medicines on opioid withdrawal syndrome. J eCAM. 2015;20(4):302-9.

5.Behbahani BA, Yazdi FT, Vasiee A, Mortazavi A. Oliveria decumbens essential oil: Chemical compositions and antimicrobial activity against the growth of some clinical and standard strains causing infection. Microb Pathog. 2018;114:449-52.

6. Khosravinezhad M, Talebi E, Shivakumar ZN, Nasrollahi I. Essential oil composition and antimicrobial, antioxidant activities of Oliveria decumbens Vent. Int J Herbal Med. 2017;5(2):102-6.

7. Amiri H, Lari Yazdi H, Dosti B, Samsamnia F. Essential oil composition and anatomical study of Oliveria decumbens Vent. J ijmapr. 2011;4(26):39-44.

8. Mahboubi M, Taghizadeh M, Khamechian T, Tamt aji OR, Mokhtari R, Talaei AS. The Wound Healing Effects of Herbal Cream Containing Oliveria Decumbens and Pelargonium Graveolens Essential Oils in Diabetic Foot Ulcer Model. World J Plast Surg. 2018;7(1):45-50. 
9. Mahboub M, Feizabadi M M, Khamechian T, Kazempour N, Razavi Zadeh M, Sasani F, et al. The Effect of Oliveria Decumbens and Pelargonium Graveolens on Healing of Infected Skin Wounds in Mice. World J Plast Surg. 2016;5(3):259-264.

10. Dashtimakan E, Roodbari F, Mohajerani M, Mahmoudiotaghvari A, Kavoosian S , Zahedi Z, et al. Antiviral Effects of Oliveria decumbens Vent. Extract against Herpes Simplex Virus Type 1.J SJIMU. 2016;26(2):113 -25.

11. Rahimi Kazerouni S, Mokhtari M, Shariati M, Rahimi Kazerooni M. Hepatoprotective effect of hydro-alcoholic extract of Oliveria decumbens against hepatotoxicity induced by cadmium chloride in adult male rat .Med. Sci. J. Islam. Azad Univ. 2015; 25 (2): 105-11.

12. Saedmocheshi S, Saghebjoo M, Vahabzadeh Z, Sheikholeslami-Vatani D. Aerobic Training and Green Tea Extract Protect against N-methyl-N-nitrosourea-induced Prostate Cancer. Med Sci Sports Exerc. 2019;51(11):2210-2216.

13. Ghasemi F, Moradi A, Izadpanah E, Moloudi MR, Hassanzadeh K, Rahimmi A, et al. Simvastatin prevents morphine antinociceptive tolerance and withdrawal symptoms in rats.J.jfma. 2015;114(5):399-406.

14. Chitme HR, Chandra R, Kaushik S. Studies on anti-diarrhoeal activity of Calotropis gigantea R. Br. in experimental animals. J Pharm Pharm Sci. 2004;7(1):70-5.

15. Honarvar A, Delaviz H, Jafari M, Roozbehi A. The effect of Hydro-Alcoholic Extract of Carum Copticum on Withdrawal Syndrome in Adult Rats Addicted to Morphine. J YUMSJ. 2016;20(11):9961010.

16. Vafaei A, Miladi-Gorji H, Taherian A, Bagerian M. Effects of Valeriane Officinalis, Satureja Hortensis, and Mentha Piperita extracts on the withdrawal syndrome signsin mice. Koomesh. 2010;12 (3):342-47.

17. Kerachian N, Alaee H, Gharavi-Naini M, Pilevarian A, Moghimi A. Effects of alcoholic extract of Avena sativa, Hypericum perforatum, Passiflora incarnata and Lavandula officinalis on symptoms of morphine withdrawal syndrome in rats. J phypha. 2007;10(4):313-21.

18. Jalilzadeh-Amin G, Mostafavi M. Effect of Hydro-Alcoholic Extract of Glycyrrhiza Glabra on Experimental Diarrhea in Mice. Med J Tabriz Uni Med Sciences. 2016;38(2):14-21.

19 Nazari P, Yaghmaei P, Rangin A, Abbasi N. The Effect of Smyrnium cordifolium Boiss. Hydroalcoholic Extract on Addiction Withdrawal Syndrome in Mice in Comparison with Clonidine. J Ilam Uni Med Sci. 2018;26(4):186-196. 